\section{Artificial stone-associated silicosis in the UK}

We read with interest the recent article by Hoy et al highlighting the risk of accelerated silicosis in workers installing kitchen and bathroom worktops. ${ }^{1}$ The Australian paper noted that artificial stone had been available in Australia since the early 2000s, and identified seven cases of silicosis diagnosed between 2011 and 2016. We were particularly interested by this, as the same type of artificial stone worktops have also been commercially available in the UK for approximately the same time period, yet there have been no published cases of accelerated silicosis from our country.

To investigate further, we interrogated the Surveillance of Work-related Occupational Respiratory Disease (SWORD) national reporting scheme database and reviewed the 161 reported cases of silicosis between 2000 and 2017. ${ }^{2}$ Interestingly, two-thirds of these cases were diagnosed in working age individuals. A review of each individual suspected cause confirmed that there have not been any cases attributed to 'artificial stone', 'artificial quartz', 'engineered stone', 'agglomerate stone', 'quartz conglomerate', 'Caesarstone', 'Silestone', 'Zodiaq' or 'resin'. In addition, there have been no cases where the occupation listed has made any reference to 'kitchen', 'bathroom', 'counter-top' or 'worktop'.

As an additional measure, we sent email requests to each member of Group of Occupational Respiratory Disease Specialists (GORDS), our national network of occupational respiratory disease specialists, but no UK cases were identified. ${ }^{3}$

It seems therefore that artificial stone-associated silicosis is yet to be described in the UK. In the absence of easily accessible industry data relating to UK usage of these products, it is not possible to know whether the lack of reported cases is real or reflects a lack of awareness among clinicians. It is possible that cases have occurred, but we could not identify them as they have been reported using non-specific terms such as pneumoconiosis in a 'stonemason' caused by 'quartz'.

It was interesting to note that the Australian cases of accelerated silicosis were typified by significant bronchoalveolar lavage (BAL) lymphocytosis, ranging from $31 \%$ to $54 \%$ in the three cases where it was performed. Similar levels of increased lymphocytes $(35-41 \%)$ on BAL cellular analysis were also noted in two Spanish cases. ${ }^{4}$ This level of BAL lymphocytosis has not previously been noted in chronic silicosis and is typically found in other lung conditions such as sarcoidosis, a condition that shares many radiological features with silicosis. ${ }^{5}$ Hoy et al also reported that 5/7 Australian cases had undergone lung biopsies as part of their diagnostic work-up. It would therefore be interesting to hear more about the Australian experience; in terms of how easily individual clinicians were able to make a diagnosis of accelerated silicosis, and whether difficulties arose in excluding 'co-incidental' sarcoidosis. It seems likely that this might be a particular issue in younger workers without extrathoracic features of sarcoid, and where job titles (eg, kitchen fitter) aren't clearly suggestive of silica exposure.

As artificial stone products are likely to be used more in Europe, it is to be hoped that the lessons have already been learned by industry, and that the lack of reported cases continues due to more effective control measures. Time will tell, but for now it is crucial that clinicians have a heightened level of awareness of this condition, and that any cases are identified as soon as possible, in order to avoid the dreadful outcomes that have been reported elsewhere. ${ }^{16}$

\section{Chris M Barber, ${ }^{1}$ David Fishwick, ${ }^{1}$ \\ Martin J Seed, ${ }^{2}$ Melanie Carder, ${ }^{2}$ Martie van Tongeren ${ }^{\circ}$}

${ }^{1}$ Centre for Workplace Health, Health and Safety Executive, Buxton, UK

${ }^{2}$ Centre for Occupational and Environmental Health, The University of Manchester, Manchester, UK

Correspondence to Dr Chris M Barber, Centre for Workplace Health, Health and Safety Executive, Harpur Hill, Buxton SK17 9JN, UK; chris.barber@hsl.gsi.gov.uk

Contributors All listed authors contributed to the development of the manuscript, identification and/ or analysis of case data and review of the final manuscript.
Funding This research received no specific grant from any funding agency in the public, commercial or notfor-profit sectors.

Competing interests None declared.

Provenance and peer review Not commissioned; internally peer reviewed.

\section{(1) OPEN ACCESS}

Open access This is an open access article distributed in accordance with the Creative Commons Attribution Non Commercial (CC BY-NC 4.0) license, which permits others to distribute, remix, adapt, build upon this work non-commercially, and license their derivative works on different terms, provided the original work is properly cited, appropriate credit is given, any changes made indicated, and the use is non-commercial. See: http:// creativecommons.org/licenses/by-nc/4.0/.

(C) Author(s) (or their employer(s)) 2018. Re-use permitted under CC BY-NC. No commercial re-use. See rights and permissions. Published by BMJ.

\section{D) Check for updates}

To cite Barber CM, Fishwick D, Seed MJ, et al. Occup Environ Med 2018;75:541.

Received 23 January 2018

Accepted 5 February 2018

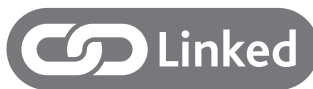

- http://dx.doi.org/10.1136/oemed-2018-105092

Occup Environ Med 2018;75:541.

doi:10.1136/oemed-2018-105028

\section{REFERENCES}

1 Hoy RF, Baird T, Hammerschlag G, et al. Artificial stoneassociated silicosis: a rapidly emerging occupational lung disease. Occup Environ Med 2018:75:3-5.

2 McDonald JC, Chen Y, Zekveld C, et al. Incidence by occupation and industry of acute work related respiratory diseases in the UK, 1992-2001. Occup Environ Med 2005;62:836-42

3 Group of occupational respiratory disease specialists. https://www.hsl.gov.uk/centreforworkplacehealth/gords (accessed 10 Jan 2018).

4 Paolucci V, Romeo R, Sisinni AG, et al. Silicosis in Workers Exposed to Artificial Quartz Conglomerates: Does It Differ From Chronic Simple Silicosis? Arch Bronconeumol 2015:51:e57-60.

5 Meyer KC, Raghu G, Baughman RP, et al. An official American thoracic society clinical practice guideline: the clinical utility of bronchoalveolar lavage cellular analysis in interstitial lung disease. Am J Respir Crit Care Med 2012:185:1004-14.

6 Kramer MR, Blanc PD, Fireman E, et al. Artificial stone silicosis [corrected]: disease resurgence among artificial stone workers. Chest 2012;142:419-24. 